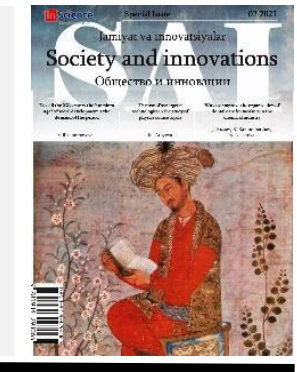

\title{
Development of media competence of future teachers
}

\section{Nasiba ABDUKADIROVA 1}

Gulistan State University

\begin{tabular}{l} 
ARTICLE INFO \\
\hline Article history: \\
Received January 2021 \\
Received in revised form \\
15 January 2021 \\
Accepted 20 February 2021 \\
Available online \\
7 March 2021 \\
\hline
\end{tabular}

\section{Keywords:}

Media literacy

Media education

Teachers

Students

The media workshop.

\begin{abstract}
The development of media and information skills in students requires advanced media competence of future teachers. The article reveals the contents of media literacy of the teacher, shows the possibility of development tools of media competency of teachers, and analyzes the experience of methodological support of development of media skills and future teacher skills. 2181-1415/C) 2021 in Science LLC.

This is an open access article under the Attribution 4.0 International (CC BY 4.0) license (https://creativecommons.org/licenses/by/4.0/deed.ru)
\end{abstract}

\section{Бўлажак ўқитувчиларнинг медиа компетентлигини ривожлантириш}

Калит сўзлар:
Медиа саводхонлик
Медиа таълим
Ўқитувчи
Талаба
Медиа студия

\begin{abstract}
АННОТАЦИЯ
Талабаларда оммавий ахборот воситалари ва ахборот кўникмаларини шакллантириш жараёни бўлажак ўқитувчиларнинг ривожланган оммавий ахборот воситалари билан ишлай олиш компетентлигини талаб этади. Мақолада ўқитувчиларнинг медиа саводхонлиги мазмуни очиб берилади, ўқитувчиларнинг медиа компетентлигини ривожлантириш учун зарур воситалар келтирилади, бўлажак ўқитувчиларнинг медиа кўникмаларини ривожлантириш бўйича методик ёрдам тажрибаси тахлил қилинади.
\end{abstract}

\footnotetext{
${ }^{1}$ Lecturer, Gulistan State University, Gulistan, Uzbekistan Email: abdukadirovanasiba2@gmail.com
} 


\section{Развитие медиакомпетентности будущих преподавателей}

\section{Ключевые слова:}

Медиаграмотность

Медиаобразование

Преподаватель

Студент

Медиамастерская

\section{АННОТАЦИЯ}

Процесс развития медийных и информационных умений
и навыков у студентов требует развитой
медиакомпетентности будущих преподавателей. В статье
раскрывается содержание медийной грамотности
преподавателя, показываются возможные инструменты
развития медиакомпетентности педагогов, анализируется
опыт методической поддержки процесса развития
медийныхумений и навыков преподавателя университета.

Today, modern information technologies are changing the process of teaching at the university. Teachers actively use a multimedia projector in the classroom (rarely a lecture is complete today without a presentation), video materials, an interactive whiteboard or panel (if technical conditions allow, for example, the availability of "fast" Internet), and combine elements of traditional and distance learning in their course. Some of the teachers have created a personal blog to communicate with colleagues, or have a personal page in a social network and post relevant information for students on it, or use online communities for professional development [1,2015, p12].

However, it should be noted that the attitude of teachers to modern information technologies today is ambiguous. If some teachers see in the computer and information technologies the possibility of solving many problems of higher education, then some of them not only do not know how to use modern teaching tools, but are also not ready to allow their presence in the educational environment.

Many students note that some teachers forbid the use of mobile phones in the classroom. What is the reason for this ban? One possible answer is to try to get students to focus on the content of the class. However, this strategy is not useful, causing only irritation. It can be assumed that the inclusion of mobile phones and I-Pads in the structure of the lesson could remove this problem and would be a productive solution. In theory, this looks convincing, but in practice, the teacher faces other difficulties: there is no interactive panel in the classroom, which means that the use of modern gadgets will not be fullfledged; the speed of data exchange with Internet resources in the classroom is so low that it makes the process of students completing educational tasks using mobile phones (for example, searching for information) unproductive. In the process of completing the training task, it may turn out that students do not know how to search and select information. In this situation, it is easier for the teacher to prohibit the use of mobile phones in the classroom [2, 2016, p 23].

The second situation can be described as follows: the teacher requires students to answer in the test or exam only the material that were given in the lessons. Students perceive this as evidence of the teacher's inertia and his/her desire to restrict their right to use a variety of sources. In our opinion, there may be another explanation for this phenomenon. It is no secret to the teacher that there is a variety of information that can relate to his/her academic subject. However, he is inclined to trust some information, selecting it for the study course. Another part of the information is considered "unreliable" by the teacher and, in his opinion, is not subject to study by students. Perhaps the teacher makes this selection based on the best intentions, realizing that students who do not have 
the tools for analyzing and selecting information can form a wrong idea about some part of professional knowledge. You can share this desire to protect the student from potential mistakes, but it is impossible to agree with the solution method [3, 2013, p.34].

Both "supporters" and "skeptics" of the use of modern information technologies in teaching ignore several important circumstances, such as:

$>$ the introduction of a computer in the educational process allows you to save the teacher from part of the routine work and create the image of a modern teacher in the eyes of the student. However, the use of modern information technologies is not a goal, but a means to solve important educational tasks;

$>$ teaching courses that are implemented in the distance learning system, using network resources without appropriate pedagogical design, do not change the fundamental characteristics of students' learning activities. They turn into "electronic libraries" and allow the teacher to finish remotely what he does not have time to do in the classroom;

$>$ "skeptics" and "supporters" of modern information technologies agree that the information age has deprived them of a monopoly on the truth, and the amount of existing and produced information requires an appropriate pedagogical response. But skeptics suggest returning to the dominance of the "living pedagogical word" in the audience, i.e., to the dominance of the teacher's speech, returning it to the status that determines the legitimacy of information. This position misses one fundamental question: "How can a student learn to independently cope with information flows in their professional activities when the teacher is not around?" Supporters believe that the use of modern information technologies in itself guarantees the development of the student's relevant skills and abilities. This means that students are assigned the status of "experts" in the use of information technologies, and it is assumed that further training should be limited exclusively to the development of highly professional information technologies by students. But the students themselves show that they are experts in the organization of communication or gaming activities with the help of modern means of communication, not being able to use them to solve other educational or professional tasks [4, 1998, p.539556].

In our opinion, even the conscious and reflexive use of modern information technologies will not allow us to fully solve the tasks that the modern information age has set for higher education. There is a need for purposeful, coordinated activities of both teachers and employees, such as the library, media center, etc., aimed at developing the student's media literacy, which will allow him to successfully operate in the modern information society.

Today, the development of the student's media literacy is relevant. In the book "Digital Future. Catalog of media and information literacy skills" contains a description of several groups of media skills and abilities, the development of which is relevant. Among them, for example: [1, 2015, p.13]

\section{Group of skills and abilities "Using information":}

Use of information sources

$\checkmark \quad$ feel the difference between the sources of information used in scientific work and in everyday life;

$\checkmark$ know how to choose the best sources of scientific information; 
the job;

know how to choose information systems according to the requirements of

understand the consequences of misusing sources in scientific work;

understand the need for references to the sources used, for example, they know how and why footnotes and biographies should be used.

\section{Search for information}

$\checkmark$ know how to search for scientific information in various sources;

$\checkmark$ freely use the most important sources of scientific information, for example, they can skillfully use library catalogues, using additional parameters, as well as databases of scientific literature;

\section{$\checkmark$ know how to develop an effective information effective strategy. \\ Critical analysis of information}

$\checkmark$ know how to use the results of discussions on the shortcomings, advantages and limitations of information sources and information and communication technology (ICT) tools to assess the quality of their work;

$\checkmark$ understand the impact of factors such as law, ethics, and economics on the development of the ICT sector, and use this knowledge in the process of solving information problems.

Group of skills and abilities "Language of media":

Language and the nature of media

$\checkmark \quad$ have an understanding of the enlightenment of reality in the media and are able to describe its role and disadvantages of perception, for example, they know how authors create media messages, how audio-visual communication differs from the direct perception of reality and why it is called the "image" of reality;

$\checkmark$ are able to explain the phenomenon of the remote presence of the object of knowledge from a philosophical point of view;

$\checkmark$ are familiar with the concept of text in a broad cultural sense, the concepts of encryption and decryption, symbol and semiotics, for example, are able to perceive a film, sculpture, architecture as a complex cultural text consisting of symbols and language codes;

$\checkmark \quad$ have an understanding of new types of media literacy, for example, they can describe not only audiovisual means of communication, but also social networks, video games, as well as analyze and characterize the image of the world created by these messages from the point of view of media genres.

\section{Media message functions}

$\checkmark \quad$ are familiar with the provisions of modern theories about the influence of advertising and marketing elements on society, for example, they can identify examples of methods of audiovisual influence used by politicians and sellers in order to convince people of their rightness or the irreplaceability of a product;

$\checkmark$ are familiar with the concept of information programs and training with elements of entertainment, can combine elements of training based on speech communication with the use of audio and visual presentations that include not only information, but also visual messages that express specific emotions, use the language of humor in the exchange of information.

\section{Culture of communication through the media}


$\checkmark$ are able to use basic rhetorical concepts, for example, they can prepare a speech and deliver it to classes at the university or take part in a radio or TV program;

understand the problems of communication and media culture, for example, can describe the main models of communication and the nature of changes in culture (for example, in language) caused by technological progress.

Group of skills and abilities "Security in the information and media environment"

Protection of personal information and reputation

$\checkmark \quad$ know the methods and means of protecting privacy;

$\checkmark$ read and understand the terms and conditions on the web pages, and make conscious decisions about accepting or rejecting these terms and conditions [.

\section{Security of communication, work, and transactions}

$\checkmark \quad$ competently use means of improving the security of communication;

$\checkmark$ are familiar with such means of inter-terminal encryption as PGP/GPG, OTR, and are able to use them [1, 2015, p.15; 5, 2010, p.53; 6, 2014, p.56-64; 7, 2001, p.89-106].

From the example given, it becomes clear that media literacy as a result of media education is not limited solely to the mastery of modern information technologies by students or to the development of skills for critical analysis of information. A broader view of the concept of media education is required. In our opinion, the introduction of a separate course aimed at developing the student's media literacy is not an optimal solution. Therefore, the formation of various groups of media competence skills requires the efforts of teachers of various academic disciplines through the inclusion of elements of media education in the content of the subject. However, is a modern teacher ready to develop a student's media literacy? What skills and abilities should a modern teacher have in order to do this professionally? With the help of what tools will a future teacher be able to develop their competence in media education?

The teacher must have a certain set of skills and abilities that would help him to organize the process of developing media literacy of students. UNESCO identifies several basic media competencies of educators:

Competence No. 1. Understanding the meaning of media and information, which includes the concept of ethics of creating news, media and information, understanding the functions of media and other information services, ethical standards of activity in the field of media and information, etc.

Competence No. 2. Understanding media content and its use cases. Within the framework of this competence, the teacher can demonstrate knowledge and understanding of various ways of using media in personal and professional life, interpret media texts and establish links between them, the context and values displayed in the media; use accepted approaches to analyze stereotypes in the media; identify, analyze and criticize advertising methods that run counter to international standards and norms of behavior, etc.

Competence No. 3. Effective and prompt access to information. The teacher can determine the type of information that is necessary for him to solve a specific task, effectively and quickly access this information; identify key words and appropriate terms for accessing the information of interest; identify different types and formats of potential sources of information, etc.

Competence No. 4. Critical assessment of information and information sources. Thanks to this competence, the teacher will be able to critically evaluate the information 
and sources of its receipt and use the selected information to solve problems and analyze ideas; evaluate the reliability, reliability, truthfulness, accuracy, authority of the source, timeliness and impartiality; recognize bias, deception or manipulation; understand the cultural, social and other contexts of information creation and understand the impact of these contexts on the interpretation of information, etc.

Competence No. 5. Application of new and traditional media formats. The teacher is familiar with the options for using digital technologies, communication tools, and networks for collecting information and making decisions; can understand the basics of digital technologies; use a wide range of media texts to express their ideas through various forms of media, etc.

Competence No. 6. Definition of the socio-cultural context of media content. The teacher can demonstrate knowledge and understanding of the processes of creating media content in a particular social and cultural context; demonstrate the ability to critically evaluate the content of local media and the role of the main ideas that they spread or perceive, etc.

Competence No. 7. Promotion of media and information literacy among students and management of necessary changes. The teacher can apply knowledge and skills to promote media and information literacy among students and manage the necessary changes in the learning environment; understand how students interpret and apply media production and messages about events in their lives; understand and apply a wide range of practical tasks to develop students ' skills in the field of media and information literacy, etc. [2, 2016, p.24; 8, 2005, p.81].

We have given as an example one of the possible classifications of media competencies of a teacher. It is obvious that a modern teacher does not have all the existing media competencies, the development of which should take place in the process of obtaining pedagogical education, and further improve. Therefore, there is a need to provide meaningful methodological support to teachers who have decided to include elements of media education in the courses taught, in the search for means of selfimprovement by the teacher of their activities.

Today, teachers have the opportunity to develop their literacy using a variety of resources, such as educational courses, seminars, professional development systems, blogs and author sites of teachers, online communities, databases of scientific information, including archives of periodicals, various media content, etc.

For the teacher, in our opinion, it is important and necessary to study and include in the educational process the resources of the university library. First, the library provides access to modern databases of scientific information that allow you to develop your own subject competence. Secondly, the databases can be used as a resource for organizing students' research activities, developing their skills to analyze and select the necessary information. For example, based on the materials of a certain database of information, students can use an algorithm for analyzing the text discussed in this article. Thirdly, the libraries provide students (and teachers) assist in the development of information competence, and allows teachers to focus their attention on other educational tasks [9, 2005, p.90].

Personal pages (websites) and blogs of teachers who have extensive experience in using modern information technologies and are ready to share this experience are an important content resource for the development of media competence of teachers. These 
resources can be useful for teachers who have decided to use training shells, video resources (laboratory classes, films, educational video channels, demo videos, and other visual aids). As a rule, these sites contain both samples created by teachers, and methodological recommendations for the development, creation and use of various methodological tools in teaching [10, 2012, p.66-72].

Teachers can find numerous articles, books, videos, methodological developments of classes, presentations of teachers' experience, etc. on the Internet. The search for these resources requires a lot of time and effort to search, analyze, and select information. Therefore, it is important to decide on a meaningful query for the search and selection of information. For example, the development of critical thinking is an important task in the process of forming students' media competence. Today, on the Internet, you can find various resources dedicated to the development of critical thinking, the materials of which can be used by the teacher $[11,2011, \mathrm{p} .110]$.

Today, the universities are able to provide support to teachers who have decided to use modern information technologies in their activities. Advanced training courses, training seminars aimed at mastering specific methodological tools by teachers, for example, the organization of training using a training shell is supplemented by a new form - a webinar. A webinar can be interpreted as a training seminar that takes place in a virtual space. To participate in the webinar, you must have a computer, Internet access, and sometimes a webcam. With some effort, the teacher can find webinars that do not require a fee for participation. The advantages of this form of training include the following:

* webinars are conducted by experienced colleagues who can not only offer some theoretical content, but also provide methodological support;

* the ability to quickly find a webinar that would match the real and relevant request of the teacher;

even if the teacher missed the time of the webinar, the organizers allow you to get acquainted with the recording;

webinars are practice-oriented in nature, and the presenters try to offer participants a variety of methodological tools that teachers can use in their activities in the future;

the teacher does not need to leave their city or country in order to participate in the seminar, which is attended by teachers from different countries.

Online communities of teachers have appeared relatively recently and are associated with the spread of various Internet resources for communication. The following communities can be distinguished: "open" (any teacher can become a member of the group) and "closed" (you can become a member of the community only after the approval of the membership request); uniting teachers of certain academic subjects (for example, business disciplines) or aimed at solving some educational task (for example, the development of media literacy of students and/or teachers); discussing some methodological tool (for example, how to use fiction or documentary films in the educational process) or aimed at educating teachers (for example, providing methodological support when creating and using a teacher's personal website), etc.

Online communities can also contribute to the development of a teacher's media literacy. Due to the large number of participants and the activity of each member of the community, a certain content field is created by placing various resources on the group's 
website: articles, monographs, videos, etc. This field is constantly updated and contains up-to-date information materials, including announcements of educational seminars, courses, and conferences that members of this community can participate in. It is important that information resources are not only placed on the community website, but also serve as a meaningful basis for discussions [12, 2014, p.120].

Group members always have the opportunity to raise a question with other members of the community and get the necessary support in the form of advice, links to the necessary resources, group discussion of the stated problem and joint search for a solution, etc. One of the types of group interaction within the community can be consultations (in real time or delayed). Most often, this opportunity arises after an educational event-a seminar, advanced training courses, and others-when the presenters of this event become members of the community. The consultation can be specially organized as a continuation of an event, or it can be used as needed. The speed of information dissemination within the group, the rich information field, the possibility of using various types of communication within the community allows us to consider the Internet community of teachers as a modern and effective tool for professional development of teachers.

The discussion of the relevance, importance and necessity of including elements of media education in the educational process takes place during the round tables and the university library within the framework of scientific and methodological conferences, scientific symposiums, etc. Round tables provide an opportunity to discuss ways of interaction between the university library and teachers, to clarify the request of teachers to provide them with methodological support, to get a clearer picture of the difficulties faced by students and teachers in the process of using modern information technologies $[11,2011$, p.111].

Discussion of educational problems, according to the teachers, has allowed them to change their approach to the curriculum design and learning activities for students more conscious approach to selection of substantial resources, to find new opportunities in the use of the funds of the library, think about the use of network resources in their activities.

In order for teachers to gain experience in distance learning and using the learning shell, the organizers of the seminar used the online learning system "Moodle". Thus, part of the educational activity was carried out at seminars, and part took place within the framework of this system of education. The analysis of the strengths and boundaries of this system is the subject of separate reflections [12, 2014, p.121].

In the near future, it is planned to further improve and develop methodological support for teachers:

* development of new seminars aimed at teaching teachers how to safely use Internet resources for teaching;

creation of a distance learning course on media literacy development for teachers who prefer this form of education;

development of methodological recommendations for the design of educational tasks aimed at the development of media literacy of students.

\section{REFERENCES}

1. Algorithm of analysis of scientific articles [e-resource]-2015. - URL: http://ru.wikihow.com (reference date: 11.11.2016). 
2. A. Fog, 2004. The Supposed and the Real Role of Mass Media in Modern Democracy. Working Paper. http://www.agner.org/cultsel/mediacrisis.pdf. accessed on February 10, 2016.

3. Digital future. Catalogue of skills of media and information education. - M. : Interregional central library of cooperation, 2013.

4. D. Lemish, K. Drotner et al., "Global Culture in Practice: A Look at Adolescents in Denmark, France and Israel," European Journal of Communication, vol. 13, no. 4, pp. 539556, 1998.

5. D. Mulyasri, 2010. Kenakalan Remaja Ditinjau dari Persepsi Remaja terhadap Keharmonisan Keluarga dan Konformitas Teman Sebaya. Skripsi. Surakarta: Universitas Sebelas Maret.

6. H.K. Mehraj, A.N. Bhat, and H.R. Mehraj, "Impacts of media on society: A sociological perspective," J. Humanit Soc Sci Invent, vol.3, no.6, pp. 56-64, 2014

7. J. Gidley, Globalization and its Impact on Youth, Journal of Futures Studies, (vol 6, no 1, August), pp. 89-106, 2001.

8. J. Mellisen, 2005. The New Public Diplomacy: Soft Power in International Relations. New York: Palgrave Macmillan.

9. J. S. Nye, 2005. Soft Power: The Means to Success in World Politics. New York: Public Affairs.

10. M. Moradi, H. Honari, S. Naghshbandi, N. Jabari, and P. Kholouse, "Social Functions of Mass Media in Developing Citizen Sports," International Journal of Academic Research in Business and Social Sciences, vol. 2, no. 6, pp. 66-72, 2012.

11. Structure of ICT competences of teachers. Recommendations of UNESCO. UNO, 2011.

12. W. Sarwono Sarlito, Pengantar Psikologi Umum, Rajawali Press, Jakarta, 2014. 